\title{
The Costing Management Model Development at University which Applies Management of Public Service Agencies (Development Model in Poltekpel Surabaya and ATKP Surabaya)
}

\author{
Efendi \\ Engineering Department, Surabaya Merchant Marine Polytechnic, Indonesia
}

Received August 31, 2021; Revised October 21, 2021; Accepted November 11, 2021

\begin{abstract}
Cite This Paper in the following Citation Styles
(a): [1] Efendi, "The Costing Management Model Development at University which Applies Management of Public Service Agencies (Development Model in Poltekpel Surabaya and ATKP Surabaya)," Advances in Economics and Business, Vol. 9, No. 4, pp. 75 - 84, 2021. DOI: 10.13189/aeb.2021.090401.
\end{abstract}

(b): Efendi (2021). The Costing Management Model Development at University which Applies Management of Public Service Agencies (Development Model in Poltekpel Surabaya and ATKP Surabaya). Advances in Economics and Business, 9(4), 75 - 84. DOI: 10.13189/aeb.2021.090401.

Copyright $@ 2021$ by authors, all rights reserved. Authors agree that this article remains permanently open access under the terms of the Creative Commons Attribution License 4.0 International License

\begin{abstract}
The purposes of this research are: (1) to find types of costing of universities which apply financial management of public service agencies in vocational education that apply boarding school system, (2) to arrange the suitable process of business for improving its graduates' competence doing more practice, (3) to know cost driver to be controlled for improving the effectiveness and efficiency. The result of this research shows that: (1) development of costing model at Poltekpel Surabaya and ATKP Surabaya through cost reduction program on cost drivers can increase competitiveness and independence in exploring sources and composition of costs, (2) planning and budget of Poltekpel Surabaya and ATKP Surabaya not yet maximal in using performance-based budgeting system, (3) need to simplify the business process at Poltekpel Surabaya and ATKP Surabaya, to compete in providing services to the community, (4) the financial management system Poltekpel Surabaya and ATKP Surabaya is good, transparent and accountable, by the provisions of the legislation, (5) the need to explore sources of financing derived from the use of assets and grants, (6) with the development of the model can increase the effectiveness and efficiency at Poltekpel Surabaya and ATKP Surabaya.
\end{abstract}

Keywords Public Service Agency, Costing Management, Cost Driver Control

\section{Introduction}

Indonesia is a country that has abundant natural wealth, a huge marine area, and thousands of islands. Approximately two-thirds of the country's territory is the ocean. Due to huge sea territory, Indonesia is also internationally recognized as a maritime country established in UNCLOS 1982 which authorizes and expands Indonesia's marine territory with all the decisions which follow it.

The great potential makes the government of President Joko Widodo want to restore the glory of Indonesia by becoming an axis maritime of the world. The government initiated a sea toll program that requires the support of all parties, as well as the role of professional shipping universities expected to produce reliable and competitive transportation resources. A college is an educational unit that conducts high education and research, as well as dedicates to the community. Colleges may take the form of an academy, a polytechnic, a high school, an institute, or a university [18].

The implementation of education cannot be separated from the use of funds or fees. The cost component in 
higher education is so varied so that it is very difficult to establish direct costs associated with education services. To carry out its principal efforts that are efficient, effective, productive, and qualified, higher education requires the formation of unit costs. By providing accurate and effective cost information, higher education can determine appropriate planning and budgeting and good decision-making. According to Chet (2001), the main difference between business management and college management can be seen in the following Table 1 .

Table 1. The Differences between Business Management and College

\begin{tabular}{|c|c|c|}
\hline No & Business & College \\
\hline 1. & It is pushed by the market & It is pushed by lecturers \\
\hline 2. & Results-oriented & Teaching-oriented \\
\hline 3. & Planned/methodical based & Open/ariseoriented \\
\hline 4. & A hierarchical relationship & Free relationship \\
\hline 5. & Decisions & Adjustment \\
\hline 6. & Low tolerance of indecision & High tolerance of indecision \\
\hline 7. & Based on the authority & Consensus-based \\
\hline 8. & High Accountability & Low Accountability \\
\hline
\end{tabular}

Source: Chet Warzynski, Cornel University

Poltekpel Surabaya and ATKP Surabaya is higher education under the Ministry of Transportation which has applied BLU (public service agency) financial management. The application of BLU cannot be separated from the agency theory. Cristensen and Leigreid [5], in a government, the agency itself involves the transfer of activities by the government to agents and can be referred to as devolution of internal structure. In the application of BLU in Indonesia, the agent is an integral part of the principal, the person who acts as principal is the technical ministry and the agent is the technical implementation unit of the ministry. Jensen and Meckling [19] describe agency relationships as "agency relationships as a contract" in which a or more person (the principals) engages another person (the agent) to perform some service on their behalf which involves delegating some decision making authority to the agent".

In conducting annual activities, each BLU is required to prepare a business plan and budget which is considered as the elaboration of the business strategic plan. Hill et al., [16] the major components of the strategic management process are defining the mission, vision, and major goals of the organization; Analyzing the external and internal environments of the organization; Choosing strategies that strengthen the external opportunities and threats; And adopting organizational structures and control systems to implement the organization's chosen strategy.

In plan and budget preparation, each activity is calculated based on the unit cost. According to budget [39] in his book managing government expenditure said "the word "budget" comes from the budget, a middle English word for the king's bag containing the money necessary for public expenditure. The budget evolved in two directions. At first, parliaments fought to take control of the budget and make governments accountable for the use of resources".

Kaplan and Norton [25] two factors affect the dynamic budget. Those are the operational budget and strategy budget. The operational budget is a budget dealing with predicting the expenditure of education program implementation both related to the management of higher education and learning management.

Jones [21] in his book "Introduction to school finance; Technique and social policy", the principles or models of educational financing imposed by the government, as follows: flat grant, full state funding, the foundation plan, guaranteed tax base, percentage equalizing, power equalizing.

Johns and Prophet [22], funding is classified into two models, which are as follows: (1) Flat grant model using fund distribution system, (2) Equalization of this model starts on the ability to pay the society.

\section{Method}

This research uses a research and development approach or research and development and it is continued by conducting the test. The method of development in this study refers to the R \& D stage model recommended by [1] with a few modifications. The location of the research was conducted at Poltekpel Surabaya and ATKP Surabaya by implementing the training of human resource development of Transportation. Referring to the criteria stated [34], the determination of the validity of the research data is based on the following criteria: (1) credibility, (2) transferability, (3) dependability, and (4) confirmability (objectivity). The development stage is presented in the following figures 1 and Figures 2. 


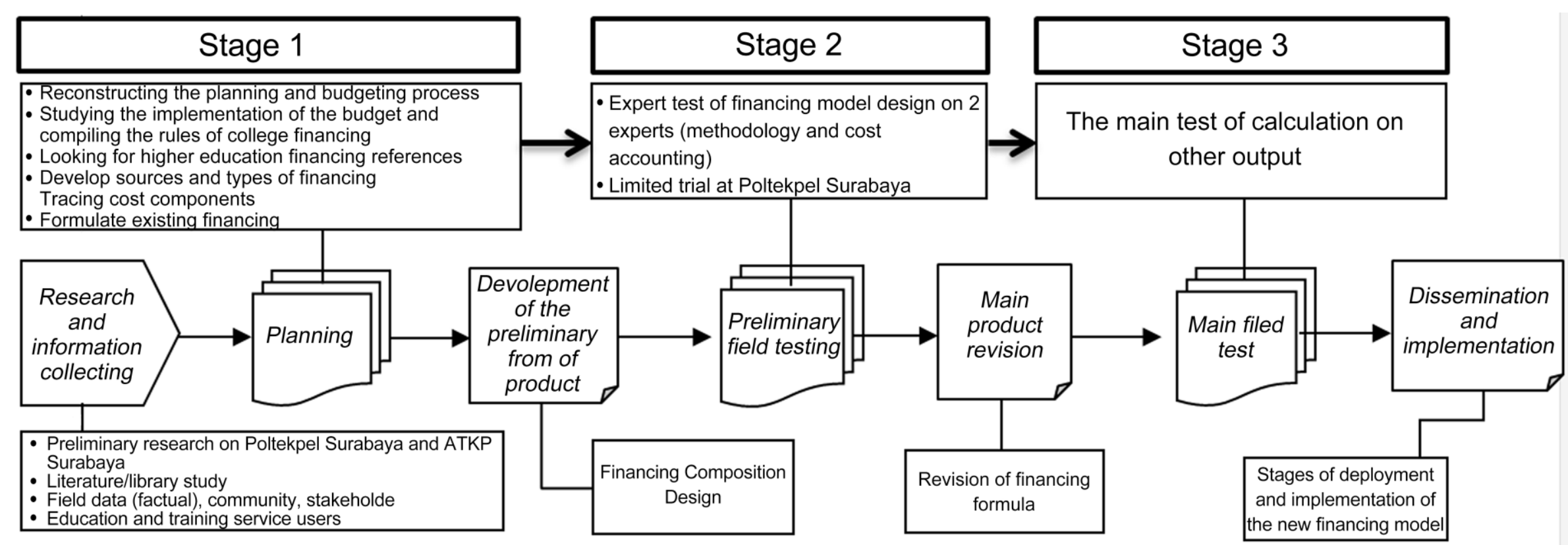

Figure 1. Stages Research and Development 


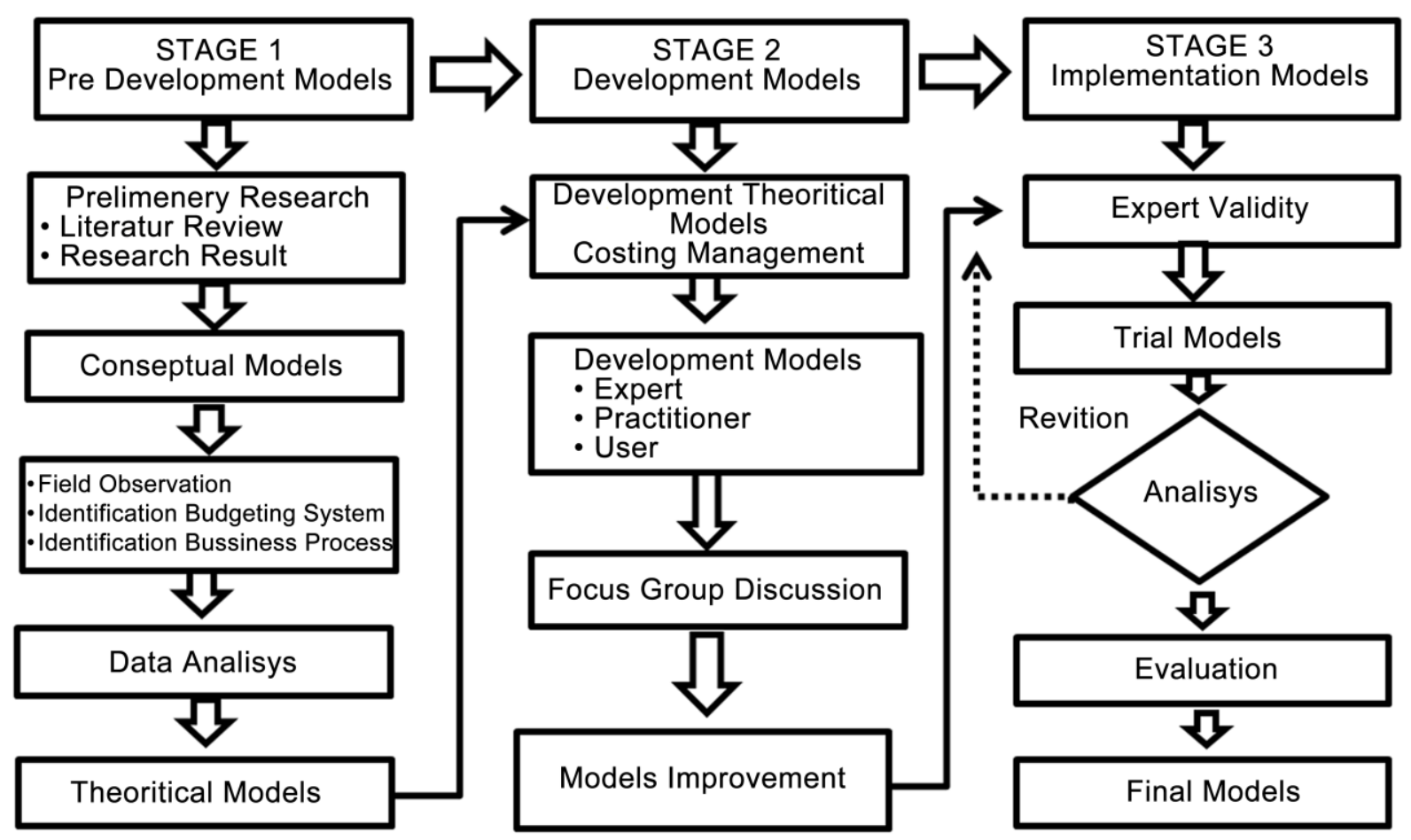

Figures 2. Flow of Research and Models Development Activities

\section{Discussion and Result}

\subsection{The Higher Education Financing Model Implementing the Financial Management of the Public Service Agency}

The flexibility of financial management, especially for planning and budgeting, is an absolute thing and must be owned by public service agencies because with this principle it is expected that universities that implement financial management of public service agencies can improve services to the community without prioritizing profits. This is in line with research on the theory of the firm: managerial behavior, agency costs and ownership. In their research [18], concluded as follows: "The publicly held business corporation is an awesome social invention. Millions of individuals voluntarily entrust billions of dollars, francs, pesos, etc. of personal wealth to the care of managers based on a complex set of contracting relationships that delineate the rights of the parties involved. The growth in the use of the corporate form as well as the growth in the market value of established corporations suggests that at least, up to the present, creditors and investors have by and large not been disappointed with the results, despite the agency costs inherent in the corporate form. Agency costs are as real as any other costs. The level of agency costs depends, among other things, on statutory and common law and human ingenuity in devising contracts. Both the law and the sophistication of contracts relevant to the modern corporation are the products of a historical process in which there were strong incentives for individuals to minimize agency costs".

\subsubsection{Development Stage}

\section{a Beginning Models}

The conclusions of the pre-development stage study results through documentation study, field observation, and in-depth interviews are included in the financing flow chart at universities that apply the financial management of public service agencies. In this stage, the existing models are refined by the inputs submitted by the experts and stakeholders in focus group discussions. Beginning models in the following Figure 3.

\section{b Development Models}

At this stage, the existing model is refined by the inputs that have been submitted by experts and stakeholders in the focus group discussion (FGD). The financing model for universities that implement improved BLU financial management can be described in the following Figure 4 . 


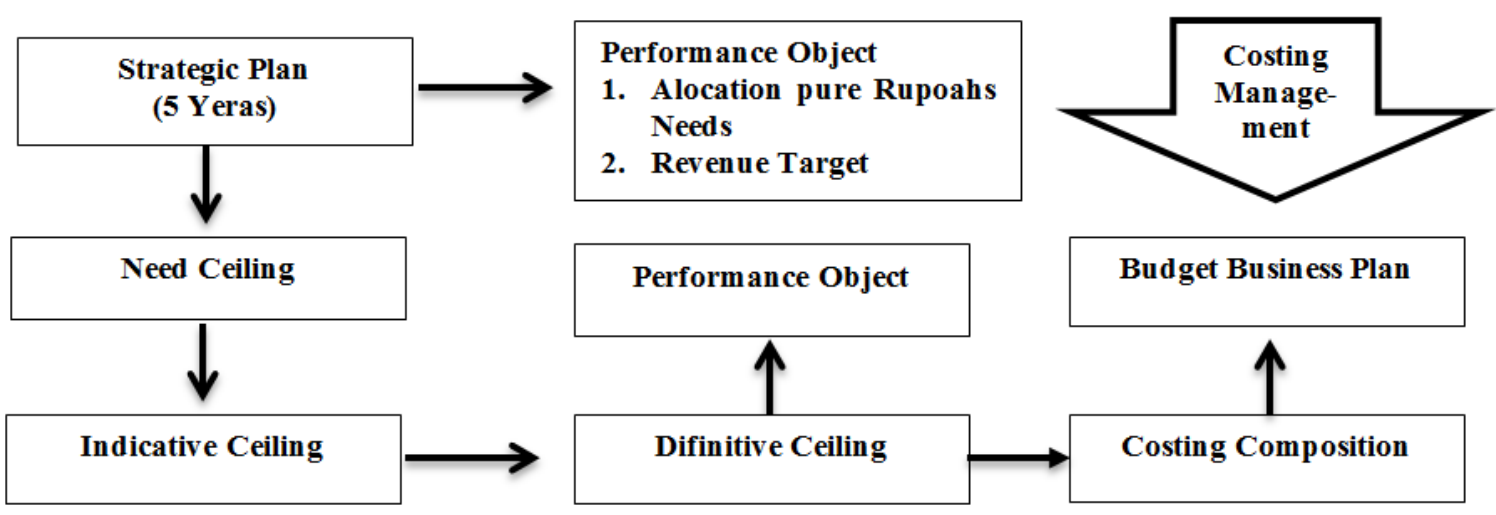

Figures 3. Budgeting Flow at The Existing Poltekpel Surabaya and ATKP Surabaya

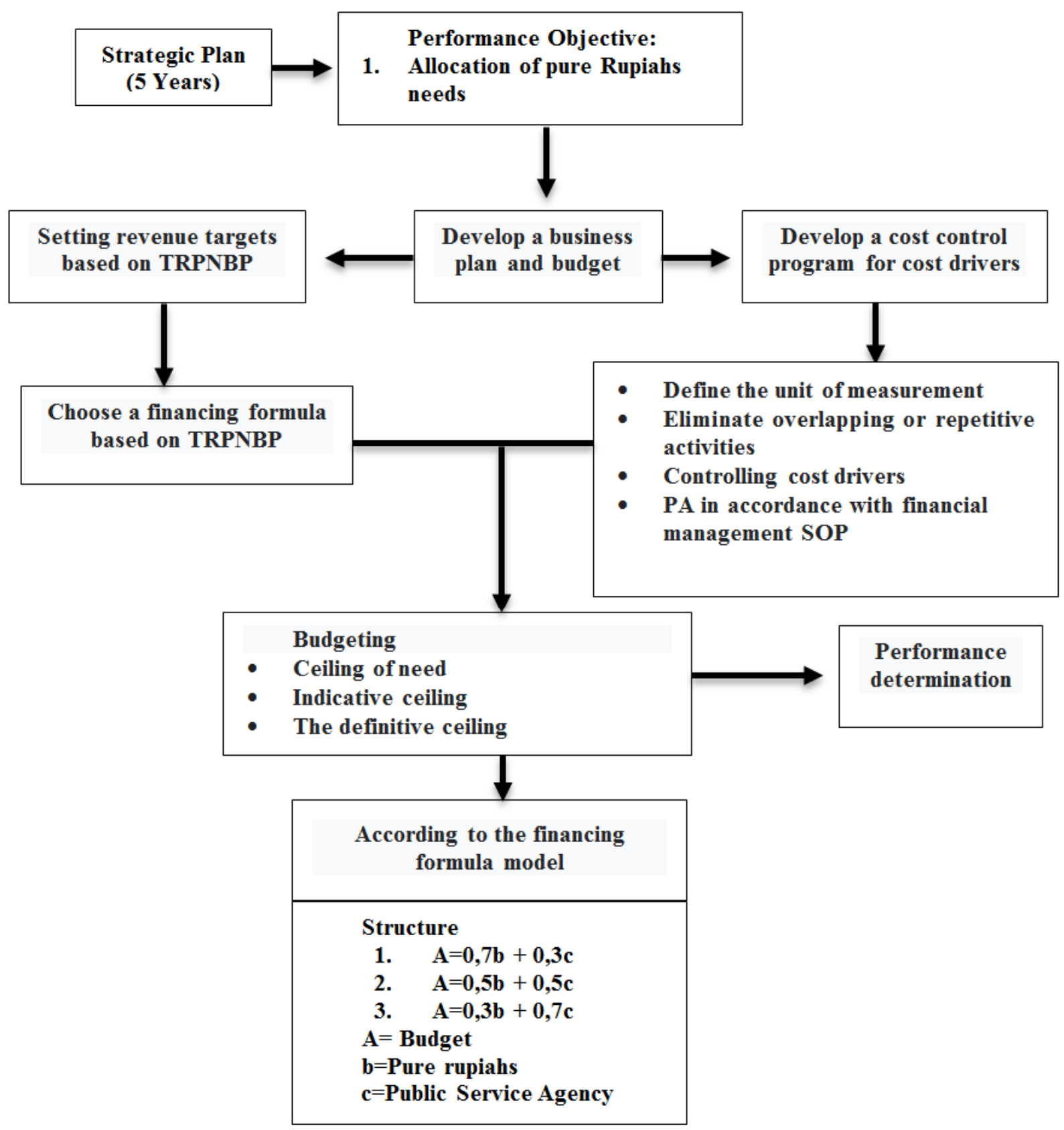

Figure 4. Development Models of Financial Management for Public Service Agency 


\subsubsection{The model Analysis}

a College planning and budgeting implementing the financial management of public service agencies.

The model which is developed by implementing the planning and budgeting process at the Poltekpel Surabaya and the ATKP Surabaya will be more flexible and self-reliant as an entity that has implemented the financial management of public service agencies. Poltekpel Surabaya and ATKP Surabaya have become more flexible and have a degree of independence in managing planning and budgeting compared to other entities.

b The business processes of Higher Education implementing the financial management of public service agencies.

According to the results of the development of the higher education finance management model implementing the financial management of public service agencies, the results obtained from the business process implementing a new model that is developed are more effective to improve the competence of the graduation. The management of teaching and learning activities is more focused on the results achieved.

c Higher Education financial management system implementing the financial management of public service agency.

The results of the existing research indicate that the presence of a college financing model implementing financial management of public service agencies is helpful for the Poltekpel Surabaya and ATKP Surabaya to improve the transparency and accountability of financial management. It can be proven that the opinion result from public accountant firm for the last 3 (three) years at Poltekpel Surabaya and ATKP Surabaya get the highest reasonable opinion without any exception.

The same thing happened in Poltekpel Surabaya and ATKP Surabaya. By implementing the financial management of public service agencies, the flexibility of financial management and financial management effectiveness get better.

d The sources and composition of Higher Education financing implementing the financial management of public service agencies.

Principal and agent relationships are stated in the performance agreement with renewal annually which has different targets from previous years. The agreement of performance between the head of BLU Poltekpel Surabaya and the Ministry of Finance consisting of financial performance and service performance is evidence that the agency theory has been implemented which resulted in the form of rewards and punishments given by the principal to the agent.

According to the agency theory concerned to solve two problems that can occur in agency relationships, an agency relationship is a contract in which one or more people (principal) ask another person (agent) to perform a service on behalf of the principal and authorize the agent to make the best decision for the principal. If both parties have the same objective to maximize the value of the company, it is believed that the agent will act consistently with the principal's interests.

Some perspectives of political, economic, social, and other sciences, [36] attempt to summarize some of the broader epistemological approaches to agency theory, as follows: (a) Economic approach, (b) Traditional social science approach, (c) Social constructive approach.

\subsection{The effectiveness of Higher Education Financing Models Implementing Financial Management of Public Service Bodies}

The level of model effectiveness is a measurement that states that the developed model has been achieved and is appropriate in the learning process and other activities. The result of the suitability test model is for measuring the effectiveness level which is presented in the following Table 2.

Table 2. Agencies Performance Score Calculation Results

Name: Merchant Marine Polytechnic Surabaya

Ministry: Ministry of Transportation

\begin{tabular}{|c|c|c|c|c|c|c|c|}
\hline No & Strategic Objective & & Indicators & Msr & Target & Result & $\%$ \\
\hline \multirow[b]{2}{*}{ I } & \multirow[b]{2}{*}{ Financial Performance } & 1. & POBO Ratio & $\%$ & 59,62 & 119,99 & 201 \\
\hline & & 2. & Revenue & IDR & $\begin{array}{c}100 \\
\text { billion }\end{array}$ & $\begin{array}{c}135,5 \\
\text { billion }\end{array}$ & 135 \\
\hline \multirow{8}{*}{ II } & \multirow{6}{*}{ Service Performance } & 3. & Percentage of graduates with GPA $\geq 3,0$ & $\%$ & 80 & 83,44 & 104 \\
\hline & & 4. & Percentage of graduates absorption $\leq 1$ year & $\%$ & 80 & 100 & 125 \\
\hline & & 5. & Number of research & $\%$ & 2 & 4 & 200 \\
\hline & & 6. & Number of CSR & $\%$ & 3 & 6 & 200 \\
\hline & & 7. & Number of lecturers (Doctoral programs) & $\%$ & 3 & 3 & 100 \\
\hline & & 8. & Index of customers satisfaction & $\%$ & 3,00 & 3,02 & 100 \\
\hline & & & Total & & & & 1166 \\
\hline & & & Average & & & & 145 \\
\hline
\end{tabular}

Source: Data Merchant Marine Polythecnic Surabaya 
Effectiveness is a key element to achieve the goals or targets which have been defined in every organization, activity, or program. It is categorized as an effective program when it achieved the goals or targets which have been determined. The result of developing a college financing model which implements the financial management of public service agencies provides concrete evidence that the effectiveness of the Surabaya Sailing Polytechnic and the Surabaya Flight Engineering and Safety Academy to achieve a goal can be well achieved.

This is in line with the notion stated by [26]. He said, "effectiveness is the ability to perform tasks, functions (operations of program activities or missions) rather than an organization with no pressure or tension between its implementation". Steers [44] argues that effectiveness is the scope of a program's efforts as a system with certain resources and means to meet its goals and objectives without paralyzing them and without imposing unnatural pressure on their implementation.

The achievement of Surabaya Sailing Polytechnic performance contract consists of: (1) Excellent service, covering: percentage of graduates with ipk> 3.00, percentage of absorption of graduates of training formation $<1$ year, the number of research conducted on the field of expertise have been presented, (2) Effective, efficient and accountable financial management performance including PNBP revenue ratio to operational cost, the realization of revenues of PNBP Year 2016, shows that the effectiveness of model development Financing at universities which apply the financial management of public service agencies can be well accounted for.

\subsection{The Efficiency of Higher Education Financing Model Implementing Financial Management of Public Service Agency}

The efficiency level of the model is a model developed in comparing the use of input plans with the use of actual usage which is lower than the previous model. The result of the suitability test model is for measuring the efficiency level presented in the following Table 3.

Efficiency is the result of a comparison between physical output and physical input. The higher the ratio of output to the input, the higher level of efficiency achieved. Efficiency can also be explained as achieving maximum output from the use of certain resources. If the output produced is greater than the resources used, the higher the level of efficiency achieved.

Hasibuan's [18] opinion state that efficiency is the best comparison between input (input) and output (outcome), between profit and cost (between execution result and source used), as well as optimal results achieved by the use of limited resources. Supriyono [46] defines efficiency as the condition when a unit can work well. So, it can achieve the expected results or objectives.

In addition, the cost reduction program in the financing formula at universities which implements the financial management of public service agencies as well as the determination of cost drivers for each activity can reduce the costs incurred by the Surabaya Shipping Polytechnic significantly.

Table 3. Model Efficiency Level Analysis Results

Budgeting Merchant Marine Polytechnic Surabaya

Years: 2016

\begin{tabular}{|c|c|c|c|c|c|c|}
\hline \multirow{3}{*}{ Programs } & \multirow{3}{*}{ Msr } & & & & & \multirow[t]{2}{*}{ Amount (in } \\
\hline & & \multicolumn{2}{|c|}{ Before } & \multicolumn{2}{|c|}{ After } & \\
\hline & & Vol & Amount & Vol & Amount & Efficiency \\
\hline $\begin{array}{c}\text { Human resources information } \\
\text { system }\end{array}$ & system & 1 & 530 & 1 & 171 & 359 \\
\hline Research report & Report & 20 & 677 & 20 & 586 & 91 \\
\hline Education and training graduate & Man & 1470 & 54.051 & 1470 & 52.135 & 1.916 \\
\hline Training support report & Report & 9 & 527 & 9 & 454 & 73 \\
\hline Office services & Month & 12 & 63.810 & 12 & 48.585 & 15.225 \\
\hline Total & & 1512 & 119.595 & 1512 & 101.931 & 17.664 \\
\hline
\end{tabular}

Source: Data Merchant Marine Polythecnic Surabaya 


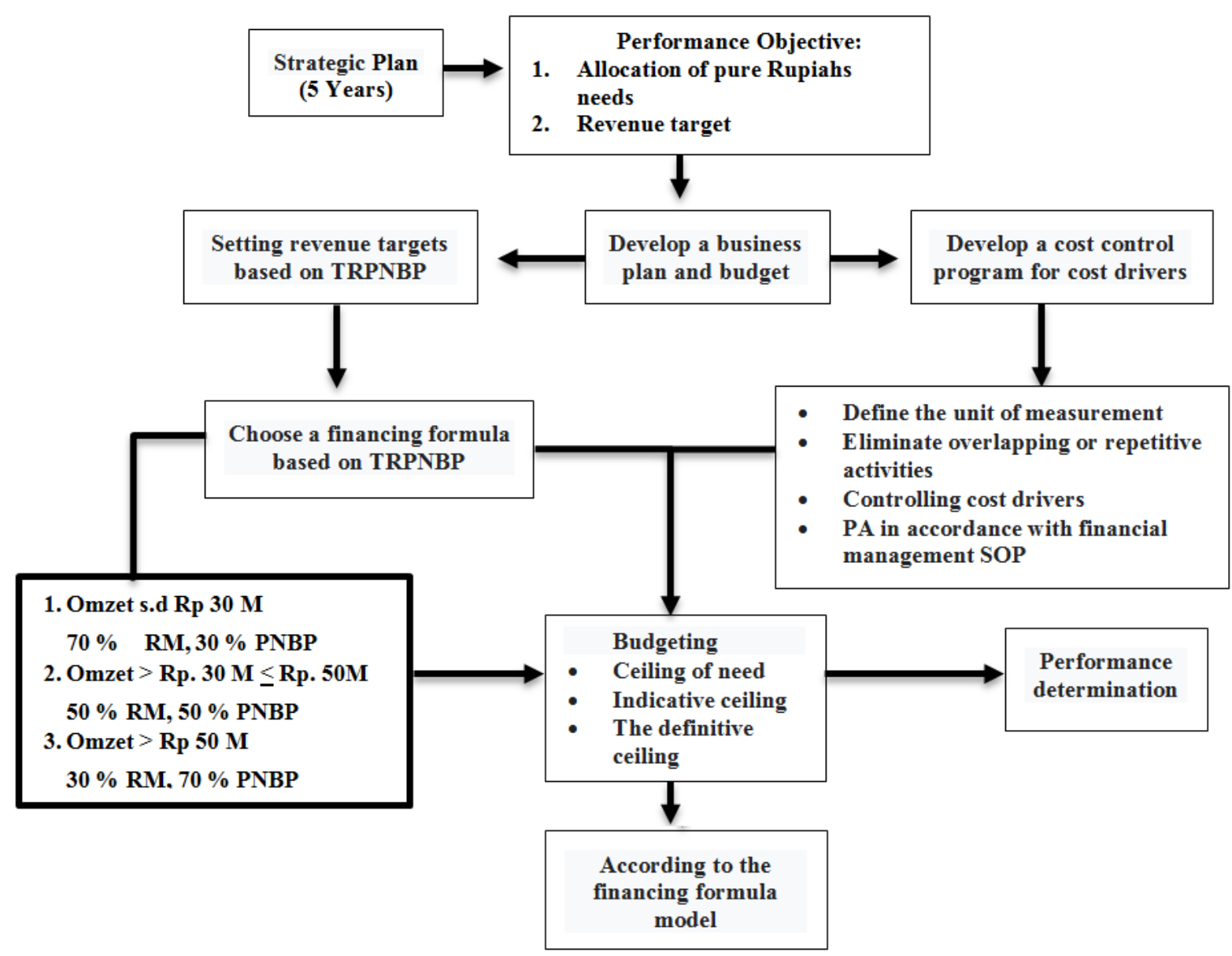

Figure 5. Recommended Costing Management Models

\subsection{Recommended Costing Management Model}

Based on the results of the experiment, the analysis of several findings, and discussion of research, researchers need to apply a model of higher education finance management which apply the financial management of public service agencies at Poltekpel Surabaya and ATKP Surabaya which is recommended as figure 5.

\section{Conclusion}

Based on data analysis and the discussion, it can be concluded some points as follows:

- The development of a financing model at higher education implementing the financial management of public service agencies with a cost reduction program on cost drivers can enhance the competitiveness and independence in exploring sources and composition of financing.

- Planning and budget of higher education implementing the financial management of public service agencies at Poltekpel Surabaya and ATKP Surabaya have not been maximized by implementing performance-based budgeting system, because the planning and budgeting system is still oriented to the output which tends to spend budget.

- It is necessary to simplify business processes at the Poltekpel Surabaya and ATKP Surabaya which has applied public service agency financial management to compete in providing services to the public.

- The financial management system of Poltekpel Surabaya and ATKP Surabaya is good, transparent, and accountable, by the provisions of the legislation; this is proven by the opinion of the public accounting firm for three consecutive years of financial statements with an unqualified opinion.

- The sources and composition of higher education financing implementing the financial management of public service agencies to the Poltekpel Surabaya and ATKP Surabaya are not only dependent on APBN, it can be obtained from the asset utilization, cooperation, and grants.

- The development of higher education financing model implementing the financial management of public service agencies at the Poltekpel Surabaya and the ATKP Surabaya can improve organizational effectiveness in achieving financial performance and service performance contracts of $145 \%$ by 2016 . 


\section{REFERENCES}

[1] Borg W R, Gall M D, "Educational Research an Introduction," 4th ed, Longman Inc, 1983, pp. 200.

[2] Cauvin E, Neumann B R, "French Cost Accounting Methods: ABC and Other Structure Similarities," Journal Cost of Management May-June, 2007, pp. 35-41.

[3] Cohn E, "The Economic of Education," rev ed, Ballinger Publishing Company, 1979, pp. 207-210.

[4] Chet W, " How Can The Balanced Scorecard Improve Performance at Your Institution," NCCI Region Conference, Pensylvania State University, USA, July 11, 2001.

[5] Christensen T, Laegrieid P, "Regulatory Agencies: The Challenges of Balancing Agency Autonomy and Political Control," Journal of Science Management 2007, pp. 499-520. DOI:10.1111/j.1468-0491.2007.00368.x.

[6] Danumihardja, M, "Manajemen Keuangan Sekolah," Jakarta: Uhamka Press, 200, pp. 47.

[7] David F R, "Strategic Management: Concept and Cases," 13th ed, New Jersey: Pearson Education, Inc, Publising as Prentice Hall, 2011, pp. 103.

[8] Denison E F,'TheSsources of Economicg Growth in The United States and The Alternative Before Us"' New York: Comitte Economic Development, 1962, pp. 308.

[9] Donald A, Lucy C J, Chis S, Asghar R,'Intoduction to Reseach in Education,"8th ed, Canada: Cengage Learnig, 2010, pp. 17.

[10] Drucker P F, "Management," rev ed, California: The Drucker Institute, 1999, pp. 26.

[11] Eisenhardt, K. M,"Agency Theory: An Assessment and Review. Academy of Management Review," Vol.14, pp.57-74, 1989. DOI: 10.2307/258191.

[12] Freeman R J, Craig D S, "Governmental and Non Profit Accounting Theory and Practice," 7th ed, Upper Saddle River, NJ, Prentice Hall, 2003, pp. 307-310.

[13] Harahap, S. S, “Teori Akuntansi," Jakarta, Rajagrafindo Perkasa, 2007, pp. 17-20.

[14] Hasibuan M S, “Organisasi dan Motivasi: Dasar Peningkatan Produktivitas," Jakarta, Bumi Aksara, 1994, pp 49.

[15] Hill, Charles, W L, Jones G R, "Essentials of Strategic Management," 3rd ed, South Western, Cengage Learning, 2011, pp. 36-38.

[16] Indarto, W, "Sebuah Pola Baru Dalam Pengelolaan Keuangan di Satuan Kerja Pemerintah," Jurnal Pendidikan Akuntansi Indonesia, vol.9, pp. 1-15, 2011. DOI: 10.21831/jpai.v9i2.962.

[17] Indrajit R Eko, Djokopranoto R, "Manajemen Perguruan Tinggi Modern," Yogyakarta, C.V. Andi Offset, 2006, pp. 118-126.

[18] Jensen M, Meckling W, "Theory of The Firm, Managerial Behavior, Agency Costs, and Ownership Structure," Journal of Financial Economics, vol 3, pp. 305-360, 1976. DOI: 10.1016/0304-405X(76)90026-X.

[19] John W. C, "Educational Research: Planning, Conducting and Evaluating Quantitative and Qualitative Research," 4th ed, Boston, Person Education Inc, 2012, pp. 673.

[20] Johns L R, Mrophet E L, and Kern Alexander K, "The Economics and Financing of Education," New Jersey, Prentice-Hall Inc, 1983, pp. 486.

[21] Johns L R, Mrophet L F, "The Economics and Financing of Education a system approach," New Jersey:Prentice-Hall Englewood Cliffs, 1975, pp. 486.

[22] Jones, T H, “ Introduction to School Finance: Technique and Social Policy,” NewYork, Macmillan Publishing Company, 1985. Pp. 117. DOI: $10.1177 \% 2 F 019263658607049130$.

[23] Juanda A, Lestari, "Analisis Perhitungan Biaya Satuan (unit cost) Penyelenggaraan Pendidikan Kedokteran," Jurnal Reviu Akuntansi dan Keuangan, vol. 2, pp. 227-241, 2012. DOI: $10.35724 / \mathrm{mjbm} . v 2 \mathrm{i} 2.2883$.

[24] Kaplan R S, Norton D. P, "The Strategy Focused Organization," Boston, Harvard Business School Press, 2001, pp. 16

[25] Kurniawan A, “Transformasi Pelayanan Public,' Yogyakarta, Pembaharuan, 2005, pp. 30.

[26] Lee Q L, "Pengertian Manajemen," Yogyakarta: B.P.A. Universitas Gajah Mada, vol.1, 2010, pp.16.

[27] Lima, C M F, “The Applicability of The Principles of Activity Based Costing System in a Higher Education Institution," Faculdade de economia de porto. Economics and Management Research Projects, An International Journal, pp. 57-65, 2011. ISSN: 2184 - 0309.

[28] Lincoln, Y. S., \& Guba, E. G, "Naturalistic Inquiry, "Beverly Hill, Sage Publication Inc, 1985, pp. 101-105.

[29] Louis C, Lawrence M, Keith M, "Research Methods in Education, 5th ed, New York: Routledge Falmer, 2005, pp. 127.

[30] Malaj A, Mema F, Hida S, "Albania, Financial Management in The Educational System," Higher Education, Bamberg Economic Research Group on Goverment and Growth, Bamberg University, 2005, pp. 2-3. ISBN 3-931052-51-6.

[31] Martin R E, "The Revenue to Cost Spiral in Higher Education. Pope Centre Series on Higher Education. Kentucky," The John William Pope Centre, 2009, pp. 47.

[32] Masdupi, E, "Analisis Dampak Struktur Kepemilikan Pada Kebijakan Hutang Dalam Mengontrol Konflik Keagenan," Jurnal Ekonomi dan Bisnis Indonesia, vol. 20, pp. 57 - 59, 
2005. DOI: $10.24167 /$ jab.v17i2.2339.

[33] Moleong L J, “Metodologi Penelitian Kualitatif,” Bandung, Remaja Rosda Karya, 2001, pp. 76-77.

[34] Pidarta M, "Analisis Data Penelitian-Penelitian Kualitatif dan Artikel: Konsep dan Contoh, 5th ed, Surabaya, Unesa University Press, 2012, pp. 27-28.

[35] Pollitt C, Tallbot C, Caulfield J, Smulen A, “Agencies: How Goverments Do Things Through Semi Autonomous Organizations," London, Palgrave Macmillan, 2004, pp. 85.

[36] Yin R K, "Case Study Research," 4th ed, London, Sage Publication Inc, 2009, pp. 222, ISBN: 978-1-412-96099-1.

[37] Rosidi A, Fajriani R A, "Reinventing Goverment, Demokrasi dan Reformasi Pelayanan Publik.,"Yogyakarta, Andi, 2013, pp. 76.

[38] Salvatore S C, Daniel T, "Managing Goverment Expenditure," 1st ed, Asian Development Bank, 1999.

[39] Shick A, "Agencies in Search of Principles," OECD, Distributed Public Governance, Agencies, Autorities and Other Goverment Bodies. Paris, OECD, 2002, pp. 33-52.

[40] Schick, A, "Opportunity, Strategy and Tactics in Reforming Public Management in OECD, Goverment of The Future," Paris, Organisation for Economic Cooperation and Development, 2000, pp. 123-148.
[41] Schick, A, "Opportunity, Strategy and Tactics in Reforming Public Management in OECD," Jounal on Budgeting, Paris: Organisation for Economic Cooperation and Development, vol. 2, 2002. Pp. 3, ISSN 1608-7143.

[42] Sonhadji A,"Manusia, Teknologi dan Pendidikan"” Malang: Penerbit Universitas Negeri Malang (UM Press), 2012, pp. 8.

[43] Steers M R, "Efektivitas Organisasi Perusahaan," Jakarta, Erlangga, 1985, pp. 15-21.

[44] Stoker G,"Theory and Urban Politics," International Political Science Review, pp.119-129, 1998. https://www.jstor.org/ stable/1601319.

[45] Supriyono, "Akuntansi Biaya Pengumpulan Biaya dan Penentuan Harga Pokok Produksi. Yogayakarta, BPFE Universitas Gajah Mada, 1977. Pp. 31.

[46] Tallbot C, "Theories of Performance: Organizational and Service Improvement in The Public Domain" Oxford, Oxford university Press, 2010. pp. 257.

[47] Wen H. T, Thomas W. L, Wen C. C, "Integrating Activity Based Costing and Environmental Cost Accounting Systems: A Casestudy, International Journal of Business and System Research, vol. 4, pp.2, 2010. DOI:10.1504/IJBSR.2010.030774. 